Article

\title{
Conspiracies, Ideological Entrepreneurs, and Digital Popular Culture
}

\author{
Aaron Hyzen ${ }^{1}$ and Hilde Van den Bulck ${ }^{2, *}$ \\ ${ }^{1}$ Department of Communication Studies, Antwerp University, Belgium; E-Mail: aaron.hyzen@student.uantwerpen.be \\ 2 Department of Communication, Drexel University, USA; E-Mail: hdv26@drexel.edu \\ * Corresponding author
}

Submitted: 29 January 2021 | Accepted: 14 April 2021 | Published: 13 September 2021

\begin{abstract}
This contribution starts from the contemporary surge in conspiracism to develop a theoretical framework to understand how conspiracy theories make it from the margins to the mainstream. To this end, it combines a view of conspiracy theories as ideology and its propagandists as ideological entrepreneurs with insights into how the affordances of digital media and popular culture are instrumental in propagating the conspiracy theories. It further complements sociological and psychological explanations with a fandom perspective to grasp the diversity of conspiracy audiences. Together, it is argued, these factors allow ideological entrepreneurs to push conspiracy theories from the margins to the mainstream. Alex Jones and QAnon are discussed as cases in point.
\end{abstract}

\section{Keywords}

Alex Jones; alternative media; conspiracy theories; digital popular culture; ideological entrepreneurs; popular culture; QAnon

\section{Issue}

This article is part of the issue "From Sony's Walkman to RuPaul's Drag Race: A Landscape of Contemporary Popular Culture" edited by Tonny Krijnen (Erasmus University Rotterdam, The Netherlands), Frederik Dhaenens (Ghent University, Belgium) and Niall Brennan (Fairfield University, USA).

(C) 2021 by the authors; licensee Cogitatio (Lisbon, Portugal). This article is licensed under a Creative Commons Attribution 4.0 International License (CC BY).

\section{Introduction}

\subsection{Because the Third Eye Ain't Open}

Trying to understand the people storming the US Capitol - the physical and symbolic heart of US democracyon January 6, 2021, early media reports unearthed an interview given to Austrian public broadcaster ORF by Jacob Anthony Angeli Chansley (or Jake Angeli), selfproclaimed shaman of conspiracy phenomenon QAnon and prominent participant in the riots:

And so, as a Shaman, I am like a multidimensional or hyperdimensional being, ok? I am able to perceive multiple different frequencies of life beyond my five senses and it allows me to see into these other, higher dimensions that these entities, these pedophiles, these rapists, these murderers, really high up people, that they almost like hide in the shadow. Nobody can see that because the third eye ain't open. (etzimanuel, 2021, 8:50m)

Hilarious nonsense to some, pathological obscurity to others, his statement was crystal clear to QAnon conspiracists. They believe in a secret, Deep State cabal of politicians, billionaires, and celebrities that they consider to be pedophiles and human traffickers that rule the world and extend their lives through the blood of abused children. These beliefs echo longer-standing conspiracies, famously promoted by Alex Jones, (now disgraced) founder of Infowars. Long before the 2017 emergence of QAnon, Jones propagated conspiracies, many based on his worldview: a fantasy-infused, idiosyncratic interpretation of Simulation Theory (Bostrom, 2003). As Jones 'explained' on the Joe Rogan Experience (PowerfulJRE, 2017): 
There's at least 12 dimensions, and all the top scientists and billionaires are coming out, saying it's a false hologram. It is artificial; the computers are scanning it and finding tension points where it's artificially projected....There is this 'Sub-transmission Zone' below the third dimension which is turned over to the most horrible things.....And our species is already way up at the fifth/sixth dimension consciousnally [sic] - our best people. But there's this war, trying to basically destroy Humanity, because Humanity has free will. And there's a decision-which level we want to go to. We have free will, so Evil is allowed to come and contend.

The January 6 events served as a powerful reminder of the mainstreaming and mobilizing powers of conspiracy theories. Conspiracy theories very much predate the current climate of $\mathrm{mis} / \mathrm{dis} / \mathrm{malinformation}$ but recent years have seen a boom in revived and new conspiracy theories and in those rallying around them. These include: Flat-Earthers, who dismiss scientific proof of a round earth as a conspiracy of the Royal Society and NASA; Birthers, refuting that former US president Barack Obama was born in the US, a presidential prerequisite; those convinced that so-called Illuminati secretly control the world, an Alex Jones favorite picked up by QAnon; Anti-Vaxxers, opposing the scientific consensus that vaccines are safe; and, recently, Covid-19 conspiracists. The latter includes debunked notions of Covid-19 as unleashed by Microsoft founder and philanthropist Bill Gates to sell vaccines and/or to plant microchips in every person, and Covid-19 being transmitted by $5 \mathrm{G}$ towers.

Academic attention has focused on the particulars of a given conspiracy theory and on psychological and sociological explanations for their attraction. Much less attention has been paid to the forces/processes through which conspiracy theories make it from the margins to the mainstream, and that is the focus of this article. We argue that this requires attention: 1) to the ideological nature of conspiracy theories, 2) to those actively propagating conspiracies, 3 ) to their use of the affordances of digital media and popular culture and, 4) to conspiracy theory followers as audiences and fans. Crucially, we argue that incorporating concepts and findings from the study of digital popular culture and its audience-fans into existing explanations of conspiracism can help us to understand the mainstreaming of conspiracy theories.

In their overview of work on conspiracy theories, Baden and Sharon (2021) mention research from fields including political communication, philosophy, social psychology, anthropology, history, law, and discourse studies, but there is no mention of a (digital) popular culture perspective. We take inspiration from scholars such as Street (2019) and van Zoonen (2005) who point out the growing convergence between politics and popular culture, politicians and celebrity, news and entertainment, citizenship and consumerism. We see this convergence at the heart of the mainstreaming of conspiracy theories. We develop a framework inspired by the literature on ideology and propaganda, on conspiracism, on digital media and popular culture's affordances as conduits for ideology, and on views on audience and fan engagement with digital content. We start from a conception of conspiracy theories as ideological and from the role of so-called ideological entrepreneurs (North, 1981) in pushing conspiracy theories to generate ideological change. We consider how their efforts to push a conspiracy-propaganda message are affected by characteristics of celebrity and of the evolving media and popular culture that serve as ideological intermediaries. We complement sociological and psychological explanations with insights from digital audience and fan studies to understand how various audiences help distribute, reinforce, or refute conspiracies. This is instrumental in pushing conspiracy theories and their propagators from the margins to the mainstream. To illustrate, we refer to "conspiracy magnate" Alex Jones and the person(s) representing $Q$ of QAnon. The focus is on the US but there are many indications that their impact goes beyond the US borders.

\subsection{Meet the Great Conspirators}

Alex Jones is a US radio show host, founder of Infowars.com and, in his words, the "most paranoid man in America" (for detailed analysis: Van den Bulck \& Hyzen, 2020). Ignoring factual evidence, Jones presents economic predictions, pseudo-science-meetspopular-culture phantasy and conspiracies emphasizing Illuminati, Deep State, and false flags (e.g., 9/11 as a US government job). As his popularity grew, so did his conspiracy spectrum, most notably in his insistence on the 2012 Sandy Hook mass shooting was a covert government operation, a so-called false flag (Van den Bulck \& Hyzen, 2020). In 2016, as part of his attack on Hillary Clinton, Jones sided with then-presidential candidate Donald Trump. He was a prominent propagator of so-called Pizzagate-a (debunked) conspiracy theory regarding involvement of top Democrats in a sex trafficking ring-and of key Democrats being lizard people, later elaborated upon by QAnon. At the height of his popularity (2017-2018), Jones and his claims attracted two million weekly listeners to his syndicated and streamed radio show, up to 1,3 billion views to his YouTube channels, and 20 million monthly visits to Infowars.com $-80 \%$ from the US. Following growing criticism and a conviction in a Sandy Hook defamation suit, in late 2018, Jones was banned from social media, affecting his ability to reach out and, to him, effectively proving the Deep State. Regardless, Jones remains in the public eye, promoting conspiracies, including President Biden as a shapeshifting lizard, appearing at alt-right rallies, and claiming strong involvement in organizing the January 6th rally and subsequent storming of the US Capitol.

QAnon originated in October 2017 when one or more people started posting under the name $Q$ on 
anonymous imageboard 4chan, later extending activities to 8 chan/8kun and beyond. Q presented itself as US insider with top military clearance and knowledge of Deep State activities. Through countless "drops" or cryptic posts, followers ("anons") are invited to become "bakers," studying crumbs of evidence to turn into dough/bread that exposes Deep State machinations (Quincy, 2018). Conspiracy topics vary, from Pizzagate to the Covid-19 pandemic as a false flag but emphasize a liberal, affluent elite of child-abusing Satan worshippers. Crucially, President Trump was presented as recruited by the US military to help fight the Deep State, an effort that followers are invited to support. In the fall of 2020, social media increasingly blocked and removed QAnon content for falsehoods and instigation of violence. $Q$ was instrumental in pushing a voter fraud conspiracy theory surrounding the 2020 US presidential elections, resulting in QAnon followers being heavily involved in the storming of the US Capitol. At the time of writing, Q's identity remained unknown, although in December 2020, Business Insider published a list of the 200 main QAnon contributors, including "celebrities, politicians, activists, military veterans, men's rights activists, media personalities, and the name of the person who probably is the mysterious ' $Q$ '”' (Edwards \& Davies, 2020).

\section{Conspiracy Theories, Ideology, and Ideological Entrepreneurs}

\subsection{Conspiracy Theories as Ideology}

The starting point is the distinct surge in conspiracism, i.e., the belief in conspiracy theories. The term conspiracy theories refers to a seemingly diverse range of theories revolving around secret activities and subversions of invisible enemies, often relating to covert government operations (so-called False Flags) and cover-ups (by the so-called Deep State). We follow Baden and Sharon (2021) and Cassam (2020), who distinguish between theories about conspiracies that have turned out to be factual-such as the propaganda campaign based on fabricated claims that Saddam Hussein had both weapons of mass destruction and ties with Al-Qaeda, which led the US into the second Iraq war-and Conspiracy Theories (Cassam, 2020) or Conspiracy Theories Proper (Baden \& Sharon, 2021) that are unproven, our main focus. Different from e.g., Baden and Sharon (2021, p. 85), we do not consider conspiracy theories as "a distinct, pathological phenomenon" but follow Aupers (2012, p. 22), who sees conspiracism as, "A cultural phenomenon that revolves around epistemological doubts about the validity of scientific knowledge claims, ontological insecurity about rationalized social systems like the state, multinationals and the media; and a relentless 'will to believe' in a disenchanted world."

Following Billig (1989), Byford (2014), and Cassam (2020), we consider conspiracy theories as ideology. Conspiracy operates as an ideological lens and (belief in it) is not so much about a theory's specifics but higherorder beliefs like distrust of authority. As such, conspiracy theories serve as smokescreens for an ideologicalpolitical agenda (Byford, 2014; Cassam, 2020). Following Thompson (1991), we consider ideology as a world view and value system, a set of beliefs held by (sections of) a society that serves not just to ensure cohesion but to maintain power relations. In this, ideologies do not so much serve as a unifying force, but legitimate the positions of and relationships between various groups. Engels and Marx (1848/1977) consider a deterministic model where the economic structure, especially the dominant superstructure's interests, bears on ideology within capitalist societies. Gramsci (1971, pp. 376-377) instead distinguishes between "historically organic ideologies... which are necessary to the structure, and ideologies that are arbitrary, rationalistic and 'willed.' " Hall $(1985$, p. 94) concurs, saying there is "no necessary correspondence" between structure and ideology. Conspiracy theories can fit either (organic or arbitrary) category and so, like ideology, do not have to follow from the superstructure. Various stakeholders of some ideological issue or another can participate in ideological formation and its circulation and can affect some material outcome. Conspiracy theories can be instrumental in this, as:

Their basic function is to advance a political or ideological objective, be it opposition to gun control, anti-Semitism, hostility to federal government or whatever. Conspiracy Theories advance a political objective in a special way: by advancing seductive explanations of major events that, objectively speaking, are unlikely to be true but are likely to influence public opinion in the preferred direction. (Cassam, 2020, p. 11)

Conspiracy theories and their following do not fit traditional party-political divisions, as is the case of Flat Earthers, Anti-Vaxxers, 9/11, or Covid-19 conspiracists. However, they tend to fall in with extremist political ideologies, be it on the left (anti-capitalist) or the right (distrust of government; Cassam, 2020). In the US, recently, conspiracy theories have become more visibly related to alt-right and populist movements, encompassing "different branches of White nationalism, including 'scientific' racists, sections of the neonazi movement, and adherents of European New Right ideology" (Lyons, 2017, para. 2), themselves increasingly connecting to the so-called manoscape. The latter involves both activist men's movements like the Proud Boys, aiming to change a status quo perceived as dominated by women, and online communities like incels, who believe in a feminist conspiracy to manipulate men and vow to stay away from women (Lin, 2017). Much attention has gone to how US President Trump embraced conspiracism and the alt-right and how the end of his term culminated in a violent convergence of conspiracism and alt-right. 


\subsection{Selling Conspiracies: The Role of Ideological Entrepreneurs}

Conspiracy theories are essentially ideological, aimed at challenging prevailing ideologies, and are generated and spread by ideological entrepreneurs. Ideological entrepreneurs, a concept introduced by North (1981), refer to figures that play a key role in ideological change and thrive in times of upheaval and alienation-a condition that also feeds conspiracism-when people are open to alternative interpretations of how things work. An ideological entrepreneur:

Would be alert to opportunities to sell a new ideology that better explains the world than existing ideologies. [They] would be a bold innovator who created new conceptions of how the world works or combined and presented existing models of how the world works in new ways (i.e., to promote ideological development). [They] would work to capture the ideological marketplace, competing fiercely against other ideological entrepreneurs as well as against the weight of existing public opinion and conventions. (Storr, 2011, pp. 107-108)

Ideological entrepreneurs can include politicians but more often are non-party actors: media personalities like right-wing radio host Rush Limbaugh, public intellectual and one of the "Four Horsemen of the Non-Apocalypse" Sam Harris; YouTube Professor Jordan Peterson, a Christian traditionalist and critic of political correctness; former Breitbart editor, neo-conservative podcaster Ben Shapiro; and, indeed Alex Jones and QAnon. The ideological entrepreneur's success is based on providing "a convincing image of a relationship between the specific injustices perceived by various groups and the larger system which the ideological entrepreneurs desire altered" (Storr, 2011, p. 108), alongside a guide to action and a clear picture of what a world will look like without these injustices. The latter can be dystopian or utopian and can compete with more scientific/common-sense/meaningful explanations. Taking Martin's (2015) simple but clear conception of ideology as values + beliefs = opinion and applying it to conspiracy-ideological entrepreneurs, they advance ideology to displace beliefs. They generate and propagate ideology expressed as alternative histories, science, political views, interpretations, amongst others, to affect public opinion and ensure followers' loyalties. As such, ideological entrepreneurs operate as propagandists. Their end goal is to challenge and displace prevailing ideologies and manipulate/manage public opinion towards conspiracy indoctrination.

As an ideological entrepreneur, Q's push of a 2020 presidential election fraud has the relationship between Deep State and traditional US politics at the heart of its conspiracy-with (President) Trump as the "savior." This has earlier roots in the ideological work of Alex Jones, who forged a relationship between conspiracism, the alt-right, and Trump politics. Identifying as libertarian and paleo-conservative, Jones made a turn to actual politics in the run-up to the 2016 presidential elections when he and Trump endorsed each other, with Jones telling Trump over the air: "Ninety percent of my listeners are Trump supporters"; and a triumphant presidentelect telling Jones, "Listen, Alex, I just talked to the kings and the queens of the world. I want to thank you, your audience" (Van den Bulck \& Hyzen, 2020). By the time Jones fell out with Trump (his 2017 order of an attack on Syria upset Jones' isolationism), crying on-air and ranting "Fuck Trump, and fuck these fucking people" (Politi, 2018), much of the ideological work was done.

However, many conspiracies pushed by Jones and $Q$ are not party-political but equally ideological: Sandy Hook, Pizzagate, lizard people, Covid-19, and 5G, the fourth dimension of evil. It can prove challenging to conceptualize such fantastical, irrational theories within any framework of rational thought or traditional ideological framework for political discourse, left/right propaganda campaigns, international conflicts, and religious affiliations. Looking closer, though, these theories serve the same ideological function as, for instance, traditional socialist or neo-liberal doctrine. Take political elites as secretly shape-shifting lizards who eat children or globalist elites as a cabal of international pedophiles. Setting aside irrationality or evidence, pushing such beliefs serves the most traditional political functions: to denigrate opposing parties, damage specific politicians or general left/right values. As such, the conspiracy-ideological entrepreneur's discourse is similar to other political theory or discourse: critiques of prevailing power and institutions, outlets of political grievances, expressions of nationalism, support of favored politicians, and demonization of rivals-all with a deeper, ideological goal.

\section{Digital Media and Popular Culture as Ideological Intermediaries}

\subsection{Getting the Message Out}

Ideological entrepreneurs need to sell their conspiracy message through propaganda, here defined as "a sustained campaign of communication to enforce ideological goals, manage opinion and codify loyalties... aimed towards consolidating identity, indoctrination and producing loyalty" (Hyzen, 2021). Our definition effectively confirms earlier notions of propaganda described as "the penetration of an ideology" (Ellul, 1965, p. 65) where "the methods of propaganda" can be deployed so that "specific allegiances and loyalties... will operate to mollify the free will" of subjects (Bernays, 1928/2005, p. 119). So, conspiracy-ideological entrepreneurs create and curate ideology in the form of conspiracy theory and elaborate this position through propaganda campaigns sustained by their own and/or third-party (social) media until the message/theory takes on a life of its own. Jones 
and $Q$, as ideological entrepreneurs, must remain relevant by producing new theories and by curating and critiquing the ever-evolving theories of others. Their modus operandi is influenced by the affordances of contemporary media and popular culture. Just like the early 20th century agitprop efforts to spread the communist message throughout Soviet Russia using popular media or ISIS posting on YouTube violent decapitation videos overlaid with ideological messages in hopes of attracting mainstream media attention worldwide, so do contemporary conspiracy-ideological entrepreneurs employ media at their disposal. Their aim: establish and maintain ideological goals and build an audience for their conspiracies through the "manipulation of significant symbols" (Lasswell, 1927, p. 627). Such symbols are not required to be of a rational nature.

\subsection{Playing the Media Game}

As the mechanism by which conspiracy theorists elaborate and spread their ideological positions and goals, propaganda has no shortage of outlets in our mediarich environment. For one, like online movements (Lyons, 2017), ideological entrepreneurs build their realm of influence and rally support through alternative-activist media. Alternative media are defined as media that compensate for the shortcomings of mainstream media and strengthen democracy through professional practices and participatory communication (Atton, 2006, p. 574). For some, conspiracist and right-wing media are not considered alternative because they develop community with closure. However, we argue that alternative-activist media refer to media that are outside of the mainstream or counter-hegemonic, can have a left-progressive (e.g., Chapo Trap House) or right/alt-right (e.g., Breitbart) orientation, and can invite participatory communication (e.g., 4chan, Reddit).

Alex Jones built his own alternative media to spread his conspiracy message (Van den Bulck \& Hyzen, 2020). In the late 1990s, he built a reputation as a radio host. Fired from broadcast radio for his radical views, in 1999, he started the online Alex Jones show that was quickly syndicated to a hundred stations through the Genesis Communications Network. He combined a daily, threehour radio show with a television show three days a week, while developing Infowars.com. Embracing the growth of social media, he developed a strong Twitter presence and created 18 YouTube channels. In 2011, he launched Infowars Nightly News TV program to anchor his new subscriber TV network. By 2017, Jones was running a multimedia business, had 2 million weekly radio listeners, and reached up to 1,3 billion views for his YouTube video channels, creating traffic to his websites that accumulated to 20 million monthly visits. As such, digital media greatly helped his visibility and reach with a more mainstream audience.

At the same time, ideological entrepreneurs exploit the web's and social media's opportunities for interac- tive participation. As Sharbaugh \& Nguyen (2014, p. 137) explain:

The significance of the Internet and social media for political change is to be seen in the way these open, networked tools empower people and organizations to privately and publicly articulate and debate a welter of conflicting views throughout society.

While this has been argued as the democratizing potential of social media, they have also been embraced by conspiracy ideological entrepreneurs. Like sections of the alt-right, conspiracism has "firm links with participatory, often fringe or even dark media networks through websites such as 4chan, 8chan, and Reddit" (Heikkilä, 2017). Claiming to champion free speech, these platforms welcome communicators who may be banned elsewhere. Alex Jones/Infowars was a popular topic on these platforms, with followers/fans dissecting and discussing his every word. QAnon's start and rise are rooted in these platforms, to the extent that, at the time of writing, some suspect the $4 \mathrm{chan} / 8 \mathrm{chan} / 8 \mathrm{kun}$ founders to be Q (Francescani, 2020). Participatory communication is at QAnon's core; Q's drops are meant to engage followers, inviting them to trace and collect evidence of conspiracies, similar to immersive games.

Crucially, we argue, the role of interactive participation in conspiracism extends beyond fringe platforms to mainstream (social) media. Paolillo (2018) analyzes YouTube as a space for Flat Earthers to come together, sharing evidence, while Lewis (2018) discusses how Facebook and Instagram influencers amplify fringe ideological messages. De Zeeuw et al. (2020) use the label "normiefication" to explain how online diffusion across culturally distinct web spheres helps counter-cultural/ subcultural messages to move from the dark web to the mainstream. Before being banned, Jones played into this by repackaging his streamed radio and television shows to fit web and social media formats, markets and algorithmic sorting and recommendation systems to reach wider audiences. Jones used social media as mainstreaming extensions and amplifiers of his alternative media and message. Similarly, mainstream social media became megaphones for QAnon's ideological messages, as anons post their fabricated proof of conspiracy on mainstream social media where they garner broad attention and following, well beyond US borders. By the time social media started banning profiles related to Alex Jones (from mid2018) and QAnon (from late-2020), these ideological entrepreneurs had achieved their mainstreaming goal.

Finally, these conspiracy-ideological entrepreneurs embrace interaction provided by digital popular culture, just like alt-right groups. The latter deploy bashing and trolling tactics as well as online memes to spread their extremist message, remixing and repurposing popular cultural references like Pepe the frog and using irony to hide their message in plain sight (Lyons, 2017). This makes it difficult to criticize and allows for 
inter-ideological mingling (Graham, 2015), spreading the message beyond primary target groups and fans to mainstream audiences, ironic spectators, and even anti-fans. Indeed, while Byford (2014, p. 10) maintains that "[t]he threat of ridicule... makes anticipating and reacting to potential or actual charges of irrationality, paranoia or prejudice, an essential feature of the conspiracy theorist's endeavour," such ridicule is not necessarily detrimental to the ideological entrepreneur's aim to catch mainstream attention. This is similar to the PR adagio: There is no such thing as bad publicity. Byford (2014, p. 14) concurs that "to cajole the mainstream into a 'debate' with the conspiracy theorist... invariably enhances the latter's status and esteem." Jones exploited his on-air antics' meme-able qualities and re-edited his media material to ignite a viral storm or hashtag war, in favor of or against his claims. Discussing the fall-out following his role in spreading the Sandy Hook conspiracy theory, he stated: "I'm under attack. And I summon the meme war, I summon it all against the enemy" (Tilove, 2019). QAnon consistently encourages followers to collect and publish proof of the Deep State conspiracies by all means possible.

\subsection{Ideological Entrepreneurs and Celebrity}

The entrepreneurs' success hinges on their ability to gain visibility and attention, often enabled by a level of celebrity within and beyond the community of core believers. Celebrity is based in mediated communication (Driessens, 2014; Turner, 2004; Van den Bulck, 2018), so it is not surprising that their primary media of communication shapes the ideological entrepreneur's visibility and renown. Alex Jones' celebrity has its basis in the radio personality: a cross-over between right-wing talk radio hosts like Glenn Beck (Jutel, 2018) and shock jocks like Howard Stern and Don Imus (Hayes \& Zechowski, 2014). His celebrity is vested, in part, in a distinct political persona as a "deep-digging" populist-conspiracist that results from the apparent merger of his public and private persona (Hyzen \& Van den Bulck, 2021) and, in part, in affective performativity, his melodramatic and exaggerated style. Together, they create a sense of authenticity: Jones IS his message. This helps attract the attention and following of conspiracy theory believers who take his message seriously and wider audiences that enjoyed and even ridicule his antics. Jones' embrace of new media and online viral culture helped him to gain further visibility and recognition beyond his primary target audience, even among those opposing his message.

While Jones' celebrity is based on the personal, Q's celebrity status results from the elusive as basic celebrity appeal. Indeed, the celebrity appeal and power of anonymity and of the (physical or symbolic) mask has a long history (Merck, 2015). Turning a feature of its media platform of choice into a tool, Q's celebrity is based on the anonymous nature of imageboards like 4chan that obscure contributors' identities while allowing for a consistent, if anonymous, identity across posts. Even though they are ideological opponents, Q's celebrity is closest to celebrity hackers collective Anonymous as well as to recent whistle-blowers whose celebrity preceded their unmasking (Coleman, 2014). It is based on being unknown but knowledgeable, necessitating anonymity while holding the melodrama of potential unmasking. As such, $Q$ illustrates the political efficacy of anonymity (Merck, 2015). In the context of Deep State conspiracies, Q's anonymity adds to the mystery. It makes $Q$ newsworthy and interesting, also for mainstream media and audiences.

\section{Duped, Empowered, or Immersed?}

\subsection{Psychological and Sociological Approaches to Conspiracism}

How to explain the attraction of conspiracy theories to what appears to be an ever-larger following? Conspiracism has caught the attention of (social) psychology, an academic domain that considers it a pathology and focuses on the brain, especially the occurrence of types (intentionality, confirmation, proportionality) of cognitive bias and on conspiracy believers' personality. By means of a Conspiracy Mentality Scale, people are identified as having a conspiracy mentality or as being conspiracy-minded. Critics (Billig, 1989; Byford, 2014; Cassam, 2020) question the methodologies (surveys/experiments as tools, make up of samples, etc.) and normative position of researchers in this field that assume "people are at fault for believing [conspiracy theories]" (Cassam, 2020, pp. 38-39) or that conspiracies are "neutral" (Byford, 2014, p. 12; see also, Billig, 1989). The approach ignores the role of ideology in people's adherence to conspiracy theories, while, for Cassam (2020, p. 45), a conspiracy mindset is not a personality trait but an ideology: "Fundamental to conspiracism is the belief that people in authority are hiding things from the rest of us as part of a conspiracy to achieve their own sinister goals." From this perspective, still according to Cassam (2020, p. 48): "The ideology of conspiracism is attractive to some because it fits their broader ideological or political commitments," which can be right or left leaning but tend to be extremist.

Taking a "sociological perspective," Byford (2014, pp. 10-11) urges us to consider conspiracism in the context of "how historically situated ideologies, worldviews and cultural traditions produce and sustain particular patterns of thinking and behaviour." In this light, Cassam (2020, p. 53) points to how earlier social developments can affect current beliefs. For instance, for members of communities that have been the victim of proven conspiracies, that context makes them more susceptible to unproven conspiracy theories. An example is the relationship between the popularity of antivax conspiracies in US black communities and the disturbing history of drug trial abuse, most notably the 
Tuskegee study (Billauer, 2020). In this context, you do not have to be an extremist to engage with the conspiracy. Others (e.g., Freeman \& Bentall, 2017) focus on how people's belief in conspiracy theories relates to feelings of marginalization and lack of agency/control. Hofstadter (2012) connects this to Durkheim's (1897/1951) notion of anomie: In a world where (you are told that) familiar norms are eroding, individuals experience powerlessness. Conspiracy theories fill the hole left by the demise of traditional political doctrine and ethnoscience, help people make sense of the world and restore a sense of control and predictability through simple, externalized explanations and the identification of an opponent.

Accounts about Jones' and QAnon's followers suggest a considerable part fits the conception of conspiracists as disenfranchised, feeling marginalized and lacking control, with the conspiracy-ideological entrepreneurs offering an alternative. Two groups can be identified. First, there is a dedicated if eclectic following of individual and loosely networked alt-right folks, libertarians, the manoscape, and doomsday preppers. Confirming the relationship between conspiracy and anomie, Socolow (2018, para. 30) says about Jones/Infowars: "They speak to-and claim to speak for-not simply the downtrodden and downwardlymobile; they also speak to those feeling wronged and forgotten." QAnon appeals to similar alt-right and manoscape groups such as Proud Boys, while Trump's explicit identification as part of the solution ensured success with Make America Great Again followers.

A second related audience is not alt-right but likewise feels abandoned by government and society. Interviewing Jones fans, Belluz (2017, para. 7) found:

The Infowarriors I spoke to didn't fit the stereotypes. Most said they believed in climate change and the benefits of vaccines. Some were former NPR listeners who felt the mainstream media had let them down. Others were looking for interesting and alternative opinions online. Still others championed science.

What brings them to Alex Jones is that they "felt let down by government, medicine and the media" (Belluz, 2017, para. 33). Reflecting on the diverse group of intruders on the US Capitol, Heath and Lynch (2021, para. 2) found that, next to alt-right: "Court documents paint a picture of a diverse mob that included both citizens with mainstream careers-police officers, a flower shop owner, a state lawmaker, military veterans, even an Olympic medalist-as well as Americans on the fringe."

Calling it a "Pottery Barn Insurrection," Bunch (2021, para. 3 ) suggests that, rather than the economic downtrodden, the January 6 rioters:

Came from lush-green suburbs all across this land, flying business class on Delta or United and staying in four-star hotels with three-martini lobby bars - the better to keep warm after a long day of taking selfies with friendly cops or pummeling the unfriendly ones, chanting "Hang Mike Pence!"

Other authors (e.g., Zuckerman \& McQuade, 2019) suggest that a considerable part of the audience does not fit either group of conspiracists.

\subsection{The Conspiracist-Fan}

Expanding the theoretical lens to digital audience studies and fan studies reflects the highly mediated nature of how followers come into contact, engage, and interact with conspiracy theories and their entrepreneurs, building on an historical interplay of audienceship and political participation (Sandvoss, 2013). Furthermore, it draws attention to a more diverse set of motivations to follow conspiracy-ideological entrepreneurs and to the dynamic nature of the involvement. With regards to the latter, social media, blogs, podcasts, and the chat boards, frequented by conspiracy theories believers, such as the QAnon' and Jones' followers, are lively places of discussion and debate, creating communities and, we could argue, fans.

Sandvoss (2005, p. 8) defines fandom as the "regular, emotionally involved consumption of a given narrative or text." On the one hand, thinking about conspiracists as fans can help appreciate the active and affective involvement of conspiracy theory believers. Work by Jenkins (2006) and Sandvoss (2013), amongst others, has shown parallels between participation in political discourse and political activism and fandom in popular culture. In both cases, such engagement becomes an important identity resource. The ideological nature of conspiracy theories informs a parallel with Sandvoss' (2013, p. 252) conceptualization of political enthusiasm "as a form of media fandom, in which [media activity] constitute forms of enunciative and textual productivity." As such, the relationship between conspiracy theories and followers is similar to an affective bond between fan objects and fans. Jones' followers demonstrate fan-like behavior in their detailed dissecting of Jones' every word in endless-now removed-threads. QAnon's basic principle is active participation and decentralized storytelling, with followers creating social media content explaining their interpretations, which Zuckerman and McQuade (2019) dubs a form of fan fiction.

On the other hand, a fan perspective can provide insight into conspiracy followers that do not fit the profile of the politically disenfranchised nor of the deeply involved conspiracy believer. Chang's (2018, para. 10) analysis of QAnon enthusiasts on Reddit found that "most participants are relatively casual conspiracy theorists.... Their interests coalesce around things like video games, cryptocurrency, men's rights, and martial arts." They come for the fun of the immersive game and the community, more than the conspiracy or the sense of regaining control. In the case of Jones, many fans are attracted not so much to his message as to his persona 
as exuberant performer. Looking at Jones' followers as audiences and fans also allows for an understanding of various ways in which his message is decoded, with their involvement being ironic and even oppositional while still embracing the experience and community. Indeed, part of his fame comes from parodies, meme culture, and remixes such as those from video creator Vic Berger who adds music and special effects to Jones' broadcasts and posts the edits on social media to popular response. These ironic spectators do not necessarily believe nor oppose Jones' ideas but enjoy his rants as entertainment and enjoy making fun of his man's man performances. This group includes members of the general public and public figures like stand-up comedian, commentator, and podcast host Joe Rogan. This type of audience is both instrumental in and part of the mainstreaming of conspiracy theories.

\section{Discussion: All Fired Up but Nowhere to Go?}

This contribution has presented a cross-disciplinary framework allowing for a contextualized understanding of contemporary conspiracism as ideological work occurring at the crossroads of politics and digital popular culture. It has pointed to the crucial role of ideological entrepreneurs that work with the affordances of digital media and popular culture to propagate their message and push it from the margins to the mainstream.

Certain conspiracies may not fit our conceptualization. For instance, conspiracy theories regarding the death of Elvis (still alive) or Princess Diana (not an accident) can be explained starting from a perspective of fandom, i.e., fans dealing with the loss of their idolized object of fandom to a random, "banal" event such as a heart attack or a car accident, rather than from a deeper ideological base. While not dismissing these cases, we argue that these examples do not undermine the notion that a majority of conspiracy theories primarily serve ideological goals. Similarly, the ideological entrepreneur's role may not always be as clearly identifiable or dominant as in the case of Jones and QAnon. We aimed to show how these entrepreneurs are instrumental in pushing conspiracies from the fringe to the mainstream. This is not a one-size-fits-all explanation but a general conceptualization that allows for different particulars of specific conspiracy theories. In a digitized environment, people move easily between individuals, groups, and institutions, merging the political and the popular, civic values and commodity. This is the context in which contemporary conspiracism flourishes. Through mediated communication and aided by the force of celebrity and popular culture, ideological entrepreneurs like Alex Jones and QAnon push their conspiracies, gathering a diverse mix of followers. These include people deeply involved in the ideological message and its promise of an empowering alternative world view, casual fans enjoying the antics (Jones) and immersive experience (QAnon) and community as much as the ideological message, as well as ironic spectators. Together, they push the conspiracy message from the fringe to the mainstream. Much more work is needed to understand these dynamics better. This will require the full conceptual and methodological toolbox available to scholars of popular culture as much as of politics and political communication.

\section{Conflict of Interests}

The authors declare no conflict of interests.

\section{References}

Atton, C. (2006). Far right media on the internet: Culture, discourse and power. New Media and Society, 8(4), 573-587.

Aupers, S. (2012). "Trust no one": Modernization, paranoia and conspiracy culture. European Journal of Communication, 27(1), 22-34.

Baden, C., \& Sharon, T. (2021). Blinded by the lies? Towards an integrated definition of conspiracy theories. Communication Theory, 31(1), 82-106.

Belluz, J. (2017, June 16). I talked to Alex Jones fans about climate change and vaccines. Their views may surprise you. Vox. https://www.vox.com/scienceand-health/2017/4/20/15295822/alex-jones-fansclimate-change-vaccines-science

Bernays, E. (2005). Propaganda. IG Publishing. (Original work published 1928)

Billauer, B. P. (2020). Covid-19 vaccination, anti-vax propaganda, and the black population. Unpublished paper. https://papers.ssrn.com/sol3/papers. cfm?abstract_id=3765525

Billig, M. (1989). Extreme right: Continuities in antisemitic conspiracy theory in post-war Europe. In R. Eatwell \& N. O'Sullivans (Eds.), The nature of the right (pp. 147-166). Pinter.

Bostrom, N. (2003). Are you living in a computer simulation? Philosophical Quarterly, 35(211), 243-255.

Bunch, W. (2021, January 12). An insurrection of upper middle class white people. The Philadelphia Inquirer. https://www.inquirer.com/columnists/attytood/ capitol-breach-trump-insurrection-impeachmentwhite-privilege-20210112.html

Byford, J. (2014). Beyond belief: The social psychology of conspiracy theories and the study of ideology. In C. Antaki \& S. Condor (Eds.), Rhetoric, ideology and social psychology (pp. 83-94). Routledge.

Cassam, Q. (2020). Conspiracy theories. Polity.

Chang, A. (2018, August 8). We analyzed every QAnon post on Reddit: Here's who QAnon supporters actually are. Vox. https://www.vox.com/2018/8/8/ 17657800/qanon-reddit-conspiracy-data

Coleman, G. (2014). Hacker, hoaxer, whistleblower, spy: The many faces of anonymous. Verso.

de Zeeuw, D., Hagen, S., Peeters, S., \& Jokubauskaite, S. (2020). Tracing normiefication: A cross-platform 
analysis of the QAnon conspiracy theory. First Monday, 25(11). https://firstmonday.org/ojs/index.php/ $\mathrm{fm} /$ article/download/10643/9998/72534

Driessens, O. (2014). Theorizing celebrity cultures: Thickenings of celebrity cultures and the role of cultural (working) memory. Communications: European Journal of Communication Research, 39(2), 109-127. https://doi.org/10.1515/commun-2014-0008

Durkheim, E. (1951). Suicide: A study in sociology. The Free Press. (Original work published 1897)

Edwards, J., \& Davies, J. (2020, December 23). What QAnon's own activists said when we told them we were publishing a list of the movement's 200 most important people. Business Insider. https://www. businessinsider.com/qanon-activists-responddatabase-of-activists-2020-12

Ellul, J. (1965). Propaganda. Vintage Books.

Engels, R., \& Marx, K. (1977). The communist manifesto. Amereon House. (Original work published 1848)

etzimanuel. (2021, January 6). QAnon shaman-Jake Angeli-Interview-ORF [Video]. https://www. youtube.com/watch? $\mathrm{v}=22 \mathrm{~d} 6 \mathrm{tRXxVeg}$

Francescani, C. (2020, September 22). The men behind QAnon. ABCNews. https://abcnews.go.com/Politics/ men-qanon/story?id=73046374

Freeman, D., \& Bentall, R. (2017). The concomitants of conspiracy concerns. Social Psychiatry and Psychiatric Epidemology, 52(5), 595-604.

Graham, R. (2015). Interideological mingling: White extremist ideology entering the mainstream on Twitter. Sociological Spectrum, 36(1), 24-36.

Gramsci, A. (1971). Selections from the Prison Notebooks of Antonio Gramsci (Q. Hoare, Ed.). International Publishers.

Hall, S. (1985). Signification, representation, ideology: Althusser and the post-structuralist debates. Critical Studies in Mass Communication, 2(2), 91-114.

Hayes, J. E., \& Zechowski, S. (2014). Shock jocks and their legacy: An introduction. Journal of Radio \& Audio Media, 21(2), 199-201.

Heath, B., \& Lynch, S. (2021, January 14). Arrested capital rioters had guns and bombs, everyday careers and Olympic medals. Reuters. https://www.reuters.com/ article/us-usa-trump-protest-cases-insight/arrestedcapitol-rioters-had-guns-and-bombs-everydaycareers-and-olympic-medals-idUSKBN29J2V8?feed Type $=$ mktg\&feedName=topNews\&WT.mc_id= Partner-Google

Heikkilä, N. (2017). Online antagonism of the alt-right in the 2016 election. European Journal of American Studies, 12(2), 1-22.

Hofstadter, R. (2012). The paranoid style in American politics, and other essays. Vintage Books.

Hyzen, A. (2021). Revisiting the theoretical foundations of propaganda. International Journal of Communication, 15, 3479-3496.

Hyzen, A., \& Van den Bulck, H. (2021). "The most paranoid man in America": Alex Jones as celebrity pop- ulist. Celebrity Studies, 12(1), 162-166. https://doi. org/10.1080/19392397.2019.1691756

Jenkins, H. (2006). Convergence culture. New York University Press.

Jutel, O. (2018). American populism, Glenn Beck and affective media production. International Journal of Cultural Studies, 21(4), 375-392.

Lasswell, H. (1927). The theory of political propaganda. The American Political Science Review, 21(3), 627-631. http://www.jstor.org/stable/1945515

Lewis, R. (2018). Alternative influence: Broadcasting the reactionary right on YouTube. Data \& Society. https:// datasociety.net/library/alternative-influence

Lin, J. L. (2017). Antifeminism online: MGTOW (men going their own way). In U. U. Frömming, S. Köhn, S. Fox, \& M. Terry (Eds.), Digital environments. Ethnographic perspectives across global online and offline spaces (pp. 77-96). Transcript.

Lyons, M. N. (2017). Ctrl-Alt-Delete: The origins and ideology of the Alternative Right. Political Research Associates. https://www.politicalresearch.org/2017/01/ 20/ctrl-alt-delete-report-on-the-alternative-right

Martin, J. L. (2015). What is ideology? Sociologia, Problemas e Praticas, 77, 9-31.

Merck, M. (2015). Masked men: Hacktivism, celebrity and anonymity. Celebrity Studies, 6(3), 272-287.

North, D. (1981). Structure and change in economic history. WW Norton.

Paolillo, J. C. (2018). The flat earth phenomenon on YouTube. First Monday, 23(12). https://firstmonday. org/ojs/index.php/fm/article/view/8251

Politi, D. (2018, April 14). Infowars' Alex Jones cries on air over Syria strikes: "Trump is crapping all over us". Slate. https://slate.com/news-and-politics/2018/04/ infowars-alex-jones-cries-on-air-over-syria-strikestrump-is-crapping-all-over-us.html

PowerfulJRE. (2017, February 1). Joe Rogan experience \#911: Alex Jones \& Eddie Bravo [Video]. https://www. youtube.com/watch?v=UZPCp8SPfOM

Quincy, P. (2018). QAnon baker's book: $Q$ drop research journal.

Sandvoss, C. (2005). Fans: The mirror of consumption. Polity Press.

Sandvoss, C. (2013). Toward an understanding of political enthusiasm as media fandom: Blogging, fan productivity and affect in American politics. Participations, 10(1), 252-269.

Sharbaugh, P., \& Nguyen, D. (2014). Make lulz not war: How online remix and meme culture are empowering civic engagement in the Socialist Republic of Vietnam. Asiascape: Digital Assia, 1(3), 133-168.

Socolow, M. J. (2018, August 8). Audiences love the anger: Alex Jones, or someone like him, will be back. The Conversation. https://theconversation.com/ audiences-love-the-anger-alex-jones-or-someonelike-him-will-be-back-101168

Storr, V. H. (2011). North's underdeveloped ideological entrepreneur. In E. Chamlee-Wright (Ed.), The annual 
proceedings of the wealth and well-being of nations (pp. 99-115). Beloit College Press.

Street, J. (2019). What is Donald Trump? Forms of "celebrity" in celebrity politics. Political Studies Review, 17(1), 3-13.

Thompson, J. (1991). Ideology and modern culture: Critical social theory in the era of mass communication. Stanford University Press.

Tilove, J. (2019, June 18). "I summon the meme war," says Alex Jones, as Sandy Hook case grows uglier. Statesman. https://www.statesman.com/blogs/ 20190618/i-summon-meme-war-says-alex-jonesas-sandy-hook-case-grows-uglier

Turner, G. (2004). Understanding celebrity. SAGE.

Van den Bulck, H. (2018). Celebrity philanthropy and activism: Mediated interventions in the global public sphere. Routledge.

Van den Bulck, H., \& Hyzen, A. (2020). Of lizards and ideological entrepreneurs: Alex Jones and Infowars in the relationship between populist nationalism and the post-global media ecology. International Communication Gazette, 82(1), 42-59. https://doi.org/ $10.1177 / 1748048519880726$

van Zoonen, L. (2005). Entertaining the citizen: When politics and popular culture converge. Rowman \& Littlefield.

Zuckerman, E., \& McQuade, M. (2019). QAnon and the emergence of the unreal. Journal of Design and Science, 2019(6). https://doi.org/10.21428/7808da6b. $6 \mathrm{~b} 8 \mathrm{a} 82 \mathrm{~b} 9$

\section{About the Authors}

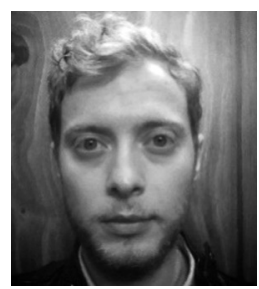

Aaron Hyzen is a Researcher in the Media, Policy, and Culture research group of Antwerp University. He is working on $\mathrm{PhD}$ that focuses on reconceptualizing the notion of propaganda by clarifying the relationships between propaganda, ideology, and political economy.

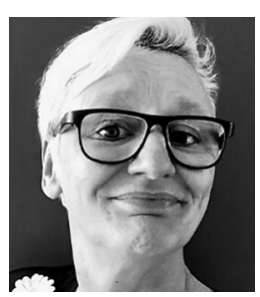

Hilde Van den Bulck (PhD) is a Professor of Communication Studies and the Head of the Department of Communication at Drexel University. She combines expertise in media structures and policies, focusing on the impact of digitization on legacy media and especially public service media, with expertise in media culture, focusing on the mediated communication in celebrity culture, especially in celebrity activism. 